\title{
INFLUENCE OF SELECTED FACTORS ON MARKETING OF PYRETHRUM PRODUCTS OF SMALL HOLDER FARMERS IN KISII COUNTY, KENYA
}

\author{
Samuel Maranga Matonda \\ Department of Business Administration, Egerton University, Kenya, P.O. Box 1441, Nakuru, Kenya \\ Mobile: +254722686827; Email: smatonda@gmail.com \\ Daniel Onwonga Auka \\ Department of Business Administration, Egerton University, Kenya, P.O. Box 1441, Nakuru, Kenya \\ Mobile: +254720656725; Email: danielauka@yahoo.com
}

\begin{abstract}
This study's main aim is to establish the influence of selected factors on the marketing of pyrethrum products from small holder farmers in Kisii County, Kenya. It examines the influence of quality related factors, Competition related factors, farmers' cooperative societies and infrastructure related factors on marketing of pyrethrum. To achieve this purpose data was collected from 274 pyrethrum farmers proportionately picked from 12 farmers' cooperative societies in 3 pyrethrum growing constituencies in Kisii County, Kenya. The results indicate that there is a positive significant influence of the selected factors on the marketing of pyrethrum products by smallholder farmers. The findings further showed that quality related factors, competition related factors, farmers' cooperative societies and infrastructure related factors jointly have a positive significant influence on marketing of pyrethrum from smallholder farmers in Kisii County. The study recommended enhancing competitiveness through support of county and National governments, and that scholars replicate the study in other pyrethrum growing counties to enhance understanding of factors that influence marketing of pyrethrum in Kenya.

Key Words: Pyrethrum, Marketing, Pyrethrins, Smallholder, Quality, Competition, Farmers Cooperatives Societies, Infrastructure
\end{abstract}

Corresponding Author: Daniel Onwonga Auka

\section{INTRODUCTION}

A report on Kenya's pyrethrum industry by the Ministry of Finance, Planning and Economic Development, Government of Kenya (GOK MFPED, 2004) records a fluctuation in demand of pyrethrum extracts in Kenya, mainly due to fluctuation in demand in the world market and also due to increasing competition from inorganic products. Most of the marketing channels available to the majority of pyrethrum farmers are long and inefficient causing delays in collection of dried flowers and in payment to farmers. Pyrethrum cultivation in Kenya dates back to 1928. The highest pyrethrum production in Kenya was realized in 1983 and from 1985 onwards, advanced technology in synthetic product innovation and aggressive promotion of the synthetic insecticides have discouraged increased production of natural pyrethrum not only in Kenya but worldwide. World pyrethrum production was about 14,000 tons of dried flowers, while demand was estimated at 20,000 tons per annum, according to the International Fund for Agricultural Development (IFAD, 2004). This market gap encouraged the increased manufacture of chemical substitutes. According to the Export Processing Zones Authority of 
Kenya (2005) pyrethrum production had been on a steady rise from 1999 to 2002. However, production at current prices, declined from KSh 1,272 Million in 2002 to KSh 782 Million in 2003.

A World Bank report (2007) identified Market access as one of the foremost factors influencing the performance of small-scale producers in developing countries. Smallholders' access to markets for higher-value or differentiated agricultural and food products is recognized as a vital opportunity to enhance and diversify the livelihoods of lower-income farm households and reduce rural poverty more generally. Recent studies have observed that the term agricultural marketing is composed of two words -agriculture and marketing. Agriculture, in the broadest sense means activities aimed at the use of natural resources for human welfare, and marketing connotes a series of activities involved in moving the goods from the point of production to the point of consumption. In principal therefore, the subject of agricultural marketing includes marketing functions, agencies, channels, efficiency, cost, market integration, and producer's surplus.

Pyrethrum marketing value chain in Kenya involves the pyrethrum farmer as the supplier of raw dry flowers, and the pyrethrum Board of Kenya as the main buyer and processor of the dry flowers delivered from the farmers. However, there are market channels such as the Farmers Cooperative Societies, the Buying Collection Centers, the Self Help Groups and the middlemen or brokers who buy from farmers and either deliver directly to PBK or through the group collection centers and farmer cooperatives. Upon processing the flowers to intermediate pyrethrum extracts and powders, buyers of these products from the PBK are the formulators. The formulators add more value to the pyrethrum powder, crude or pale extract from the PBK processing.

\section{Selected Factors Influencing Marketing of Pyrethrum}

For the purposes of this study, four factors assumed to influence the marketing of pyrethrum from small holder farmers were selected. These are quality related factors, competition related factors, farmers' cooperative societies and infrastructure related factors. Recent studies on smallholder farmers suggest that their problems to access markets are many (Barham \& Chitemi, 2009). The smallholder farmers' problems place farmers as price takers rather than price setters, mainly due to poor market access and consequent limited bargaining power. Further, literature suggests that perceived product quality is one of the eight dimensions that shape the quality concept. The others are performance, features, reliability, and conformance to specifications, durability, aesthetics, and serviceability. In a report by the World Food Programme (WFP, 2015) it is observed that although smallholder farmers produce most of the developing world's food, they also make up the majority of people living in poverty. Smallholder farmers are pivotal to addressing many of today's social, economic and environmental challenges. Many smallholders lack the equipment and knowledge they need to produce large quantities of quality crops, the report adds.

Given that pyrethrum is a natural insecticide from pyrethrum crop, its competition is both from products that serve the same function such as synthetic pyrethroids, and it can also be from other crops such as tea, coffee or food crops competing for the same land resources. Smallholder farmers make purchasing and consumption decisions, as well as production and marketing decisions regarding their farms. Choices include which crops to produce, which crops to sell, which crops to consume, how much livestock to raise, what food products to buy, what inputs to use, whether to work on or off the farm or both, as well as many more.

When making important decisions, smallholders take into account a variety of factors, including but not limited to production costs, transportation costs, risk, revenue, prices, wage rates, and food security concerns (Fischer \& Qaim, 2012). For smallholder farmers to thrive in the global economy, it is necessary to shift from product-orientation to market-orientation interventions. Farmer groups such as 
Self Help Groups and Farmers' Cooperative Societies have been identified to play a key role as an efficient mechanism for enhancing marketing performance for smallholder farmers (Kariuki, 2006).

Transportation costs are especially relevant for farmers in developing countries, as they often have fewer roads on which to travel, and if they have paved roads, they are regularly in poor condition. Infrastructure is typically poor in rural areas limiting market access for agricultural produce. The farmers lose a large proportion of their harvest to rot and mould due to lack of storage facilities. Coupled with limited market information and poor transportation infrastructure, farmers generally sell to traders for low prices directly from their farms, leaving them with little income. Not only do better post-harvest handling practices and storage technologies allow farmers to retain more of their harvest, they also allow them to store their crops for longer periods, benefiting from sales for higher prices at a later time, the report adds (WFP, 2015).

\section{Problem Statement and Purpose}

Marketing is important in identifying the customer needs, developing products to meet the needs, costing the product appropriately for affordability and profit while making the product available to the convenience of the customers. In marketing, quality related factors are exhibited in the product specifications. Important too is the understanding of the competition, both direct and indirect. This understanding of the competition helps position the product in the market through its unique selling proposition. To be able to make the product available to the customer, the channel of distribution is vital, and for smallholder farmers, group marketing is ideal in consolidating quantities, while observing quality requirements. Finally, the product has to be warehoused and transported, in its various forms to the customer; hence the importance of infrastructure in marketing of pyrethrum (Kotler \& Keller, 2006).

Various studies focusing on factors affecting the performance of pyrethrum sector suggest that brokers dominate most pyrethrum marketing channels and charge fees for their services which reduce the famers' revenue. This is because the payments are determined by deducting these intermediate costs from the respective amount offered by PBK to farmers for flowers delivered. A further review of past studies suggests that there is little empirical knowledge about the factors influencing the marketing of pyrethrum products by small holder farmers. Therefore, this study sought to examine the influence of selected factors related to quality, competition, farmers' cooperative societies and infrastructure on pyrethrum marketing by smallholder farmers in Kisii County.

\section{Objectives of the Study}

1. Establish the influence of quality related factors on marketing of pyrethrum products of smallholder farmers in Kisii County

2. Establish the influence of competition related factors on the marketing of pyrethrum products of smallholder farmers in Kisii County

3. Determine the influence of farmers' cooperative societies on the marketing of pyrethrum products of smallholder farmers in Kisii County

4. Determine the influence of infrastructure related factors on marketing of pyrethrum products of small holder farmers in Kisii County

5. Determine the joint influence of quality related factors; competition related factors, farmers' cooperative societies, and infrastructure related factors on the marketing of pyrethrum of smallholder farmers in Kisii county. 


\section{Research Hypothesis}

The following hypotheses were tested:

$\mathbf{H}_{01}$ : There is no significant influence of quality related factors on marketing of pyrethrum products by smallholder farmers in Kisii County.

$\mathbf{H}_{\mathbf{0 2}}$ : There is no significant influence of competition related factors on marketing of pyrethrum products by smallholder farmers in Kisii County.

$\mathbf{H}_{\mathbf{0 3}}$ : There is no significant influence of farmers' cooperative societies on marketing of pyrethrum products by smallholder farmers in Kisii County

$\mathbf{H}_{\mathbf{0 4}}$ : There is no significant influence of infrastructure on marketing of pyrethrum products by smallholder farmers in Kisii County.

$\mathbf{H}_{05}$ : Quality related factors, competition related factors, farmers' Cooperative societies, and infrastructure related factors jointly do not have a significant influence on marketing of pyrethrum products by smallholder farmers in Kisii County

\section{Significance of the Study}

Globally, pyrethrum is viewed as an ideal pesticide in the current environmentally conscious climate. Kenya is well positioned to take advantage of this positive market trend. The study findings will benefit the Ministry of Agriculture in Kenya to adopt customized strategies in marketing the pyrethrum products. The findings will also assist the Pyrethrum Regulatory Authority as they endeavor to develop supportive policies to improve quality, competition, farmers' cooperative societies and infrastructure to enhance pyrethrum marketing. Since agriculture is a devolved function, this study will inform the 18 pyrethrum growing counties while making their County Integrated Development plans to prioritize pyrethrum as a cash crop. Infrastructure improvement is one major area of focus for the counties to facilitate transportation of flowers to the market, bringing sales revenue to the county governments.

Pyrethrum crop is an important cash crop since its introduction in Kenya in 1928. This study will enrich the scholars with knowledge and understanding of the influence of selected factors on the marketing of pyrethrum products of smallholder farmers in Kisii County. It will also stimulate further research for scholarly critiquing and for possible consideration of further studies to build a repository of knowledge on Kenya Pyrethrum.

\section{LITERATURE REVIEW}

This section reviews the theoretical perspectives of smallholder marketing, and delves in the past research relevant to this study. The study is founded on collective group marketing theories. The section further presents a model that links product factors to the marketing of smallholder pyrethrum products. It finally focuses on four selected factors likely to influence the marketing of pyrethrum products by smallholder farmers, presented in a conceptual framework at the end.

\section{Marketing of Agricultural Products}

Collective action has become an important strategy for smallholders in developing Countries to remain competitive in rapidly changing markets (Fischer \& Qaim, 2012). Smallholder organization in farmer groups is seen as a possible institutional solution to overcome high transaction costs and other market failures in developing countries (Markelova, Meinzen, Hellin \& Dohrn, 2009). Literature has examined determinants of group membership, focusing on farm and household characteristics, such as farm size, wealth, education, or gender (La Ferrara 2002; Bernard \& Spielman 2009). This partly overlaps with studies on the impacts of group membership in terms of market access, prices, and income (Bernard et 
al. 2008; Narrod, Roy, Okello, Avendaño, Rich, \& Thorat 2009). Another literature focus line has scrutinized structural and institutional aspects of farmer groups, such as group size, stringency of rules, commodity focus, and market conditions (Barham \& Chitemi 2009; Narrod et al., 2009). Yet, one aspect that has hardly been analyzed empirically is the intensity of participation of individual members in different group activities. This is considered a research gap, which was addressed in an article by (Fischer, \& Qaim, 2010). Tegemeo Institute of Agricultural Policy and Development is a Policy Research Institute of Egerton University that conducts research and analysis on policy in the domain of Agriculture, rural development, natural resources and environment. Tegemeo Agricultural Monitoring and Policy Analysis Project, Kenya found out that pyrethrum in Kisii faces stiff competition from other agricultural enterprises such as horticulture and dairy which earn higher returns.

Sustainable agricultural development requires proper coordination of production, processing, distribution and marketing functions in harmony with natural resource systems. The success of these processes greatly depends on existence of effective institutions that are able to respond to both local and global changes in the commodity markets, as well as in the policy frameworks (ADB, 2005). Livelihood improvement from commercial agriculture also varies considerably with the level of stakeholder participation in decision-making (FAO, 2002). National statistics (Republic of Kenya, 2005a) indicate that pyrethrum would provide more robust income throughout the cropping year unlike seasonal crops. Distortions in policy environment and markets have been cited in some previous studies as key constraints to the pyrethrum industry in Kenya (IFAD 2004; Republic of Kenya, 2004b). However, no attempts have been made to rank the constraints, and this makes it difficult to prioritize solutions for policy action given scarce resources. These studies also highlighted stiff competition resulting from synthetics and imports of processed pyrethrum products, as well as challenges of tight international trade requirements, but failed to suggest coherent mechanisms for addressing the impediments.

Hundreds of millions of smallholder farmers in developing countries face serious obstacles in advancing from subsistence farming to higher-value-income pathways. Barrett (2008) outline the prospects of smallholder farmers and Chapoto et al. (2013) provide detailed scenario options for smallholder farmers. They also offer sobering analyses that highlight the scale of the problems faced by smallholders and the generational timeframe it takes for even a few to escape rural poverty through farming. These studies stress that market linkage is not a panacea. Most smallholder farmers are unlikely to ever shift to high-income pathways. Extension services must be flexible to meet the needs of these different types of farmers. These authors conclude that there are numerous factors that affect farmers' prospects in the value chain and with establishing market linkages. These factors include location and business maturity within a target area, as well as access to infrastructure, agricultural services, and water and production technologies. The skills, education, and organization of the farming community are also important aspects in terms of their ambitions, discipline, and ability to plan, set goals, and follow an implementation schedule. It is important to consider these factors when deciding whether to invest in a particular area to ensure that project designs improve market linkage prospects.

In a strategic paper to develop cooperatives societies in South Africa, it is revealed that there are many constraints faced by smallholder farmers, (Republic of South Africa, 2012). The strategy reveals the lack of access to land, lack of reliable markets for their produce, non-value addition to their products, lack of human capital, high transaction costs, declining agricultural productivity, inability to modernize due to limited land sizes, limited market access, increasingly costly market regulations, poor physical and institutional infrastructure as some of the constraints. High transaction cost and lack of proper roads in the remote rural areas limit the ability of a farmer to transport farm inputs from, and farm products to the market. Ultimately, lack of reliable markets is a major constraint bedeviling the 
smallholder farmers. Farmers are forced to sell their products at the farm gate, fetching very poor prices.

Markets cannot be known to exist if there is no access to information about their existence, and their product requirements. Therefore, lack of access to market information, and market channels favoring market access is a key hindrance to market access by the smallholder farmers. Human capital lacks in many smallholder farms, and affordability of the available skilled services is not within the reach of the farmers. There is increasing global consumer demands on food, health and safety. This makes it difficult for smallholder farmers to enter high-value markets in light of low quantity and poor quality of their products. Smallholder farmers are inconsistent in their production, with seasonal varying quantities and quality. This makes them unreliable suppliers, hence are not preferred by buyers. This also reduces their bargaining power, leading to poor prices for their products. Information is vital to inform and to help make decisions. However, for smallholder farmers, lack of access to timely, accurate market information robs them of the advantage to locate the best markets, and prevents them from selling at peak market prices.

\section{Smallholder Issues in the Pyrethrum Sector}

Smallholder farmers are defined differently depending on the context, country and ecological zone. The term "smallholder farmer" is most often used interchangeably with "peasant farmer', "resource poor farmer", or "small scale farmer". A typical smallholder farmer is a simple, small-based owner of a plot of land, growing food crops with a mix of some cash crops if any, but mainly utilizing family labour. In most cases, smallholder farmers' production systems use outdated technology, realizing low returns with seasonal labour fluctuations. Women play a vital role in smallholder farming production. Smallholder farmers have to make decisions on farm allocations, resource distribution between food and cash crops, livestock and other on-farm activities (Gadzikwa, Lyne, \& Hendriks, 2007).

Smallholder farmers contend with poor roads and high transportation costs. The farmers select crop activities based on cost, revenue and profit but are constrained by labor requirements, cash requirements, food security concerns, and input and output market access. Market access is directly related to distance to market, since distance to market increases the cost of inputs, increases transportation costs, and reduces the effective price farmers receive for outputs. In most parts of Africa including in Kenya, smallholder farmers are the engines of growth of their national economies.

In an effort to address the challenges facing the sector, the Pyrethrum Act was reviewed in 2013. According to the Act every smallholder grower, for purposes of accessing economies of scale, shall have the freedom to register with a licensed pyrethrum processor, who shall keep for statistical purposes a register of all pyrethrum growers so registered. There is established an authority to be called Pyrethrum Regulatory Authority. The functions of the authority shall be to develop and promote the pyrethrum industry. It shall register processors, formulators and persons running pyrethrum nurseries. It shall also co-ordinate the activities of stakeholders and organizations within the pyrethrum industry. The principal objective of the Act was to liberalize the market and reward high quality and improved efficiencies. Despite all these efforts, intended impact has been minimal.

\section{Product Quality and Smallholder Marketing}

The concept of Good Agricultural Practices (GAP) has evolved in recent years in the context of a rapidly changing and globalized agricultural economy. This is mainly a result of the concerns and commitments of a wide range of stakeholders to balance agricultural production and security with agricultural safety and quality and environmental sustainability of agriculture. The Food and Agricultural Organization (FAO) with a number of stakeholders developed a conceptual framework for 
Good Agricultural Practices. Broadly defined, the GAP applies to recommendations and available knowledge to addressing environmental, economic and social sustainability for on-farm production and post-production processes resulting in safe and health food and non-food agricultural products.

In Kenya the Pyrethrum Act 2013 gives the Pyrethrum Regulatory Authority the powers to set the required pyrethrum standards. PBK products are registered in USA, Canada, European countries, Japan, Australia, India, and in some countries in Africa. Major data packages have been generated for registration and regulatory authorities that include; the European Biocide Directive, European Drug Master File, United States Environmental Protection Agency (USA-EPA), United States Food \& Drugs Agency (USA-FDA), European Agricultural Directive (91/414/EEC), International Co-operation on Harmonisation of Technical Requirements for Registration of Veterinary Products, International Federation of Organic Agriculture Movement, and the Soil Association. All these bodies measure and approve pyrethrum products quality.

All flower deliveries from the fields are inspected for quality, weighed, sampled and analyzed for Pyrethrin content at the former Pyrethrum Board of Kenya laboratories. They are then stored under carbon dioxide or directly passed to the various processing stages according to requirements, such as manufacture of powders or extracts. Every stage of processing undergoes a rigid control system. All factory inputs are routinely analyzed for conformity with specifications. In-process control employs methods of analysis such as Gas Liquid Chromatography, Thin Layer Chromatography, Ultra Violet and Infra-Red Spectrometry as well as the High Performance Liquid Chromatography (HPLC). Before release to a customer the former PBK laboratories inspect all products by use of state of-the-art analytical methods. Each shipment is accompanied by a Certificate of Analysis (CoA) to testify compliance of the product with its specification as well as regulations of the receiving country or its specific use. Each shipment is also accompanied with a Material Safety Data Sheet (MSDS). Policies that strengthen property rights and institutional management structures and capacities would provide incentives for beneficial participation by farmers and other stakeholders in the pyrethrum value chain. Effective targeting of pyrethrum products to niche markets, competitive pricing, reduced transportation costs and mitigation of post-harvest losses also contribute to improved enterprise performance (WBCSD, 2004).

Quality is regarded by most producers as one of the most important aspects of manufacturing, service and purchasing strategies. Several studies, for example, Aaker and Jacobson (1994), Buzzell, D., Gale, T. \& Sultan, R. G. M., (1975), Capon, N., Farley, U. \& Hoenig, S., (1990), and Anderson (1992), have reported that perceived product quality is related to increased sales and profits and consumers make their purchase decisions in relation to perceived quality. These studies show that perceived product quality is one of eight dimensions that shape the quality concept, the others are: performance, features, reliability, conformance, durability, aesthetics and serviceability (the intrinsic attributes or physical characteristics of a product).

Expanded pyrethrum production will increase growers' earnings despite of the problem of low producer prices that strongly militate against the production and marketing of good quality pyrethrum. Pyrethrum farmers are paid based on the quality of their dry flowers and especially on the pyrethrins content (PBK). The pyrethrins content is a factor of variety / clone of pyrethrum grown, the geographical conditions, crop husbandry including harvesting, drying, storage and delivery lead times. Since pyrethrins breaks down in sunlight and on exposure to ultra violet light, long storage periods lead to low pyrethrins content, and hence low payments to farmers (PBK manual). There is wide acceptance of diversified uses of pyrethrum products, such as their application as herbicides and stabilizers (Jovetics, 1994). The environmental-friendly nature of pyrethrum also makes it quite useful as a critical component in most pesticide formulations worldwide. 
Strategies of accessing emerging export market opportunities (especially in Asia and the Middle East) have also not featured in previous studies. Value addition provides a good option for diversifying use of pyrethrum products and raising farm incomes. Indeed, aggressive processing of primary commodities for export markets contributes significantly to employment creation, increased raw material production, improved investment in infrastructure development and increased export value, especially in the Newly Industrialized Countries such as Malaysia and Thailand (Ganewatta et al., 2005).

Kenya exports 97 percent of its pyrethrum products as crude or refined pyrethrin while only 1 percent is processed for use in the domestic market (EPZA (2005). There is, therefore, a wide scope for adding value to locally produced pyrethrum. One of the key determinants of the value of pyrethrum is its pyrethrin content, which is affected by the type of seedlings planted, crop husbandry and processing practices. Some studies have noted failures in Kenya's pyrethrum institutions and expressed the need to reform those institutions. However, no clear reform path that fully incorporates all stakeholders' views is suggested by these studies. For instance, the IFAD (2004) study recommended replacement of the government-run PBK with a private company, the Pyrethrum Company of Kenya (PCK), but failed to indicate the best method of constituting the PCK and the desired stakeholder representation. Another study on Kenya's pyrethrum sub-sector (Kariuki, 2006) suggests the need for enhanced value addition and institutional governance, but largely ignores the role of farmers in these essential value chain transformation processes, yet farmers are the owners of the pyrethrum industry in Kenya. The foregoing gaps in literature present a daunting task in regaining the competitiveness of Kenya's pyrethrum industry, more so toward sustainable development. This study therefore sought to address some of these challenges, with the aim of improving smallholder stakeholder participation in pyrethrum products marketing, and ensuring a stable future for the country's pyrethrum sub-sector.

\section{Competition and Smallholder Marketing}

According to the Institute of Economic Affairs, IEA (2001), Pyrethrum was first introduced in Kenya in1928 from Europe and, by 1933, the first commercial crop was exported mainly to Europe (Contant, 1979). Kenya pyrethrum was of high-quality and hence quickly replaced the Japanese pyrethrum on the world market by 1941. At its peak, Kenya was the largest single producer of pyrethrum in the world accounting for over 70 per cent of the world market. Other producer countries are Tanzania, Uganda, Rwanda, Ecuador, Papua New Guinea and lately Tasmania in Australia. Recent studies further observe that Pyrethrum is an expensive insecticide, so it is not surprising that the chemical industry has attempted to develop synthetic equivalents Pyrethroids are manmade insecticides that have a chemical composition which closely resembles Pyrethrin.

In the fight for market share, competition is not manifested only in the other players. Rather, competition in an industry is rooted in its underlying economics, and competitive forces that go well beyond the established combatants in a particular industry. Porter (1997) identifies customers, suppliers, potential entrants, and substitute products as competitors that may be more or less prominent or active depending on the industry. New entrants to an industry bring new capacity, the desire to gain market share, and often substantial resources. Companies diversifying through acquisition into the industry from other markets often leverage their resources to cause a shake-up, as Philip Morris did with Miller beer.

Porter (1997) further explains the seriousness of the threat of entry. This depends on the barriers present and on the reaction from existing competitors that entrants can expect. If barriers to entry are high and newcomers can expect sharp retaliation from the entrenched competitors, obviously the newcomers will not pose a serious threat of entering. Initially, ground pyrethrum flowers were used as 
a raw material input for making mosquito coils and powdered insecticides and resulted in a limited customer base. Success in the extraction and refining of purified pyrethrins from the flower gave this natural insecticide much broader applications, such as water-based aerosols that SC Johnson pioneered. According to Abbot (1988), there has been increasingly greater recognition of the value of natural pyrethrum and pyrethrins for use in household insecticide products. The US is the single biggest market today, and only major American buyers of purified extract remain, most of which are distributors who purchase from the former PBK and later resell to manufacturers.

During periods of shortage, some pyrethrum consuming companies shifted supplies, in full or in part, to synthetic pyrethroids to reduce their supply risk and save costs. The insecticide market has been consuming approximately 60 percent synthetic Pyrethroids and 40 percent natural pyrethrins (PBK, 2014).

\section{Farmers' Cooperative Societies and Smallholder Marketing}

Hudson and Herndon (2002) introduce a farmer cooperative as a business organization owned and controlled by its members for their mutual benefit. Members finance their cooperative through equity investments. Control comes via membership rights to vote for and become directors. The directors hire the manager and establish the policy under which the manager operates. While the manager and directors have little direct control over the external environment, they do have control over and the responsibility for how the cooperative adjusts to a continuously changing world environment.

Quint (2014) also observes that while many cooperatives may have struggled and disappeared, others have recast themselves in order to cope better with the changes in global markets. Cooperatives and rural associations are now resurgent business forms in Africa. It is once again accepted that farmer organizations offer a way to exploit the potential of collective action in order to access markets more effectively, to take advantage of organizational opportunities to overcome financial cash and investment constraints, and information asymmetries, and to exploit scale economies in production and marketing. Thurston (1984), noted that the potential therefore for farmer associations to improve the livelihoods of the rural population and contribute to a decrease in poverty may well depend on a new generation of dynamic and alternative forms of commercial organization.

A smallholder farmers' association is made up of cooperatives or farmer field schools or farmer producer marketing groups (FAO, 2001). These common groups are created and financed by farmer members to provide them with services that help improve their economic and social conditions (Gatarwa \& Place, 2005). An association is a form of collective action; the farmer groups undertake a voluntary action to achieve a common interest (Meizen-Dick, 2004). Collective action typically arises in instances where there are significant incentives to cooperate (Van Heck, 2003).

The British Colonial Authorities launched a major agricultural development initiative which laid the foundation of Kenya's post -independence agricultural prosperity. This initiative known as the Swynnerton Plan was implemented between 1954 and 1963 and was the largest small holder development programme ever implemented by the Colonial Authorities in Africa. It was anchored on intensification of agricultural production in the Central and Rift Valley Provinces coupled with the establishment of an effective and efficient post-harvest processing and marketing infrastructure. Infrastructure includes both physical infrastructures such as rural roads, markets; warehouses and processing factories as well as institutional infrastructure such as the Small-holder Crop Development Authority [SCDA]. The SCDA evolved into the Kenya Tea Development Authority [KTDA] which was regarded in the 1960s as the most successful integrated institutional innovation for agricultural development. 
The CDAs for Cotton; Coffee; Tea; Dairy; Livestock, Sisal; Pyrethrum, and Tobacco were established to handle input supply as well as output marketing and processing. Limited support services from extension providers has been observed, leading to the promotion and development of farmers' cooperative societies (FCS), to reduce poverty, unemployment, and high levels of inequality. FCSs are known to address the smallholder farmers' constraints. Smallholder FCS aims to attain improved sustainability and scope of products offered through creation of economies of scale; improved logistics in terms of storage and transportation facilities; Assist in ensuring compliance with food safety and quality assurance standards; Improved market intelligence; Improved bargaining power to ensure fair trade; Lowering of transaction costs as a result of bulk buying; Improved access to best available technology to improve production efficiencies and quality of products; and Ensure that there are value adding and agro-processing facilities.

Monda (2014) observes that the Pyrethrum Growers Association of Kenya (PGA) is a Business Membership Organisation registered under the Societies Act with its headquarters in Molo. It was established in 2001 to represent the interests of the small scale pyrethrum growers. The formation of PGA was initiated by the pyrethrum growers prompted by the decline in pyrethrum production and a desire for farmers to voice their problems and grievances to the government and other stakeholders. Pyrethrum growers in Kisii belong to cooperative societies, and the Masaba Farmers' Cooperative Union through which marketing of pyrethrum is conducted. The collection centers which are managed by the cooperatives serve as consolidation and holding centers. Payments to farmers are also channeled through the cooperatives (PBK, 2014).

\section{Infrastructure and Smallholder Marketing}

Kenyan traders in agricultural produce face high transportation and other transaction costs due to poor roads and other market inefficiencies. These costs have been shown to influence the agricultural sector as they influence the difference between farm gate prices and retail prices in the final consumer market - the marketing margin. Marketing margins influence farm gate prices of farm inputs and the retail prices of farm produce. As such, they are major determinants of the competitiveness of produce and products in domestic as well as international markets, access to inputs, household incomes, expenditure and access to food. Efficiency and cost reduction in marketing of agricultural produce is of paramount importance to the success or survival of the agricultural sector. The marketing channel adopted and also external factors outside the area of influence of those involved in marketing influences the magnitude of marketing costs.

Cooperatives face many problems and issues, both internally and externally. Cooperatives generate nearly Ksh11.050 trillion in revenue and offer 200,000 jobs (Deller et al., 2009). Cooperatives operate under a business model that generates unique challenges in financial management, governance, strategy and communication. The fact that agricultural cooperatives are governed by producer members is both a key strength and a key challenge for cooperatives. Hueth and Reynolds (2009) summarize the issues and need for future research in this area. The key governance challenge is that of identifying and recruiting directors with the essential mix of skills. Member involvement in a cooperative is another key issue which often relates to their access to board members or interest in running for the board. Other governance issues identified by the panel were related to the effectiveness and performance of the board of directors. The addition of outside, non-member directors has been a recent development in agricultural cooperatives, and according to the panel, is an important issue facing modern cooperatives. The local traditional market is usually maintained in areas where transportation is almost impossible for the rural population with its limited means. And the goods and services are intended for local consumption. The local market is usually located in a market place. This is a site in which the goods 
offered change from season to season. Such local markets form a network, in which one market is linked to another through the passage of goods, services and people. The local market is a meeting place of occasional sellers, who set up at random in sales shacks, and come together at fixed time intervals at that fixed site. This is where goods and services are distributed between the villagers, who act both as buyers and sellers.

Literature records that the ability of the cooperative to transport its produce on its own is generally considered a great advantage. The cooperative can choose the most suitable means of transportation, the transportation capacity employed as well as the direction of transportation according to its needs and capabilities. Many cooperatives in developing countries assume that the development of the transportation function within the cooperative framework means that the cooperative must purchase the vehicles, but this is incorrect. It turns out that the purchase of a truck by the cooperative is done without conducting the necessary economical examination. It is generally the case that the truck capacity is not put to full use most of the year, except at harvest time. And then it is often insufficient. An additional problem is truck maintenance. In most cases the cooperative hires a driver, and such drivers receive a very low pay in most countries of the world. Thus it is important to note the significant role that infrastructure plays in the facilitation of products movement to the consumers. Due to the biodegradable characteristic of pyrethrins, delays in delivery of dry flowers to PBK exposes the flowers to degradation and a drop in pyrethrins content. This directly reduces the farmers' earnings which are based on pyrethrins content. This delay in delivery of flowers to PBK eventually affects the processing schedules which in turn cause unreliable customer supplies (PBK).

\section{Conceptual Framework}

In this study, the dependent variable is marketing of pyrethrum products and the independent variable is Selected Factors of Quality related factors, Competition related factors, Farmers Cooperative Societies and Infrastructure related factors. The variables and how they are related is shown in Figure 1.

Quality of pyrethrum products is mainly measured with by the pyrethrin content, moisture content and cleanliness Pyrethrum is paid based on the pyrethrin content and quantity of the product. Competition is perceived to be faced from alternative products replacing pyrethrum as an insecticide, other pyrethrum growing countries which fight for the same global market share for pyrethrum, and crops being grown instead of pyrethrum. The Farmers cooperative societies are an important channel for marketing of produce from small holder farmers. This is mainly for ease of collecting and consolidating quantities enough for bulk transportation and collective marketing. In this study Infrastructure focuses on road network and storage facilities. This is all aimed at establishing that pyrethrum does not lose its pyrethrin content before reaching the market for processing, because pyrethrum disintegrates readily on exposure to sunlight, and water.

The four selected variables of quality, competition, farmers' cooperatives societies and infrastructure are expected to influence marketing of pyrethrum products since pyrethrum quality depends on crop husbandry. For instance, if pyrethrum is intercropped with other nutrient and space competing crops, the quality of the flowers is bound to deteriorate. On the other hand, smallholder crops need to be consolidated in order to pool enough volumes or quantities to attract a sustainable market. Therefore, farmers' cooperative societies (FCS) play the role of consolidation whereas infrastructure maintains the quality of the products, while in warehouses or on transit to the market. It is expected that all the four selected factors play a complementary function in regards to marketing of pyrethrum products from small holder farmers. However, the influence of the selected factors on marketing is expected to be moderated by environmental factors such as weather and politics. Overall, it is expected that all the 
four selected factors jointly influence the marketing of pyrethrum products; however, the degree of influence of each factor will be established.

Independent Variable

\begin{tabular}{|l|}
\hline \multicolumn{2}{|c|}{ Selected Factors } \\
Quality \\
- Pyrethrin Content \\
- Moisture Content \\
- Cleanliness \\
Competition \\
- Crops Competing for \\
- resources \\
- Alternative insecticides \\
$\quad$ Pyrethrum producing \\
Farmerries \\
Societies Cooperative \\
- Pyrethrum Farmers' \\
- Group flower collection \\
- Group flower marketing \\
Infrastructure \\
- Road network \\
- Storage facilities \\
- Processing factory \\
\hline
\end{tabular}

Moderating Variable

\section{Environmental Factors}

- Weather

- Politics

\section{Dependent Variable}

Figure 1: Relationship between Quality, Competition, Farmers Cooperative Societies, and Infrastructure related factors and Marketing

\section{MATERIALS AND METHODS}

\section{Research Design}

This study adopted a correlational and cross-sectional survey research design to examine the influence of individual dependent variables of quality related factors, competition related factors, farmers' cooperative societies and infrastructure related on the independent variable of marketing of pyrethrum by smallholder farmers in Kisii County. By adopting the correlation and cross-sectional survey research design data was collected over a short period of time across the sample elements. The survey was limited to eliciting views from the pyrethrum farmers about the influence of the selected factors on the marketing of their pyrethrum. 


\section{Area of Study}

Kisii County is located in western Kenya and it has 9 administrative constituencies. It has a population of 1,152,282 as per the 2009 census, 245,029 households and covers an area of 1,317.4 sq km. The population density stands at 874.7 people per sq. $\mathrm{km}$ and $51 \%$ of the population lives below the poverty line. The growth of cash crops such as tea, coffee, pyrethrum and subsistence crops such as maize, beans and potatoes are supported by the red volcanic soils.

\section{Target Population}

The population of the study comprises of pyrethrum farmers in Kisii County, who are also members of the 12 Farmers Cooperative Societies in the County. These cooperative societies together with 17 others from Nyamira County form the Masaba Farmers Cooperative Union. The target population therefore was drawn from 950 farmers as received from a farmers' register at Masaba Farmers Cooperative Union. The population was drawn from members of the twelve (12) pyrethrum Farmers' Cooperative Societies in the three constituencies of Kisii County. The 12 FCSs in Kisii County are shown in Table 1.

Table 1: Pyrethrum Farmers Cooperative Societies in Kisii County

\begin{tabular}{|l|l|l|l|}
\hline FCS & FCS & FCS & FCS \\
\hline Gesusu & Ibacho & Nyangusu & Nyacheki \\
\hline Masimba & Nyamasibi & Kiobegi & Majimazuri \\
\hline Kiamokama & Ramasha & Nyamache & Nyanturago \\
\hline
\end{tabular}

Source: Masaba Farmers' Cooperative Union, 2014

\section{Data Analysis and Interpretation of Results}

Data analysis consists of examination, categorization, and tabulation of the evidence to address the initial propositions of the study (Kothari, 2009). Once data was collected it was edited to eliminate errors and improve its quality, coding followed before a detailed analysis using the Statistical Package for Social Sciences was done. Coding is defined as the analytical process through which "data are fractured, conceptualized and integrated to form theory" (Strauss \& Corbin, 1998). Both qualitative and quantitative techniques were used to analyse the data. Data was analysed by use of descriptive statistics (mean, standard deviation, variance and percentage). Pearson correlation coefficient was used to test hypotheses $\left(\mathrm{H}_{01}\right.$ to $\left.\mathrm{H}_{04}\right)$. Multiple regression model was used to test hypothesis $\mathrm{H}_{05}$. The following model was used:

$Y=a+\beta_{1} X_{1}+\beta_{2} X_{2}+\beta_{3} X_{3}+\beta_{4} X_{4}+\varepsilon$

Where: $\mathrm{Y}=$ Marketing of Pyrethrum Products

$\mathrm{a}=$ constant;

$\mathrm{X}_{1}=$ Quality related factors;

$\mathrm{X}_{2}=$ Competition related factors;

$\mathrm{X}_{3}=$ Farmers' Cooperative Societies;

$\mathrm{X}_{4}=$ Infrastructure related factors

$\beta_{1}$ to $\beta_{4=}$ regression coefficients;

$\varepsilon=$ error term 
Table 2: Correlation Matrix for Relationship between Selected Factors and Marketing of Pyrethrum Products among Small Holder Farmers

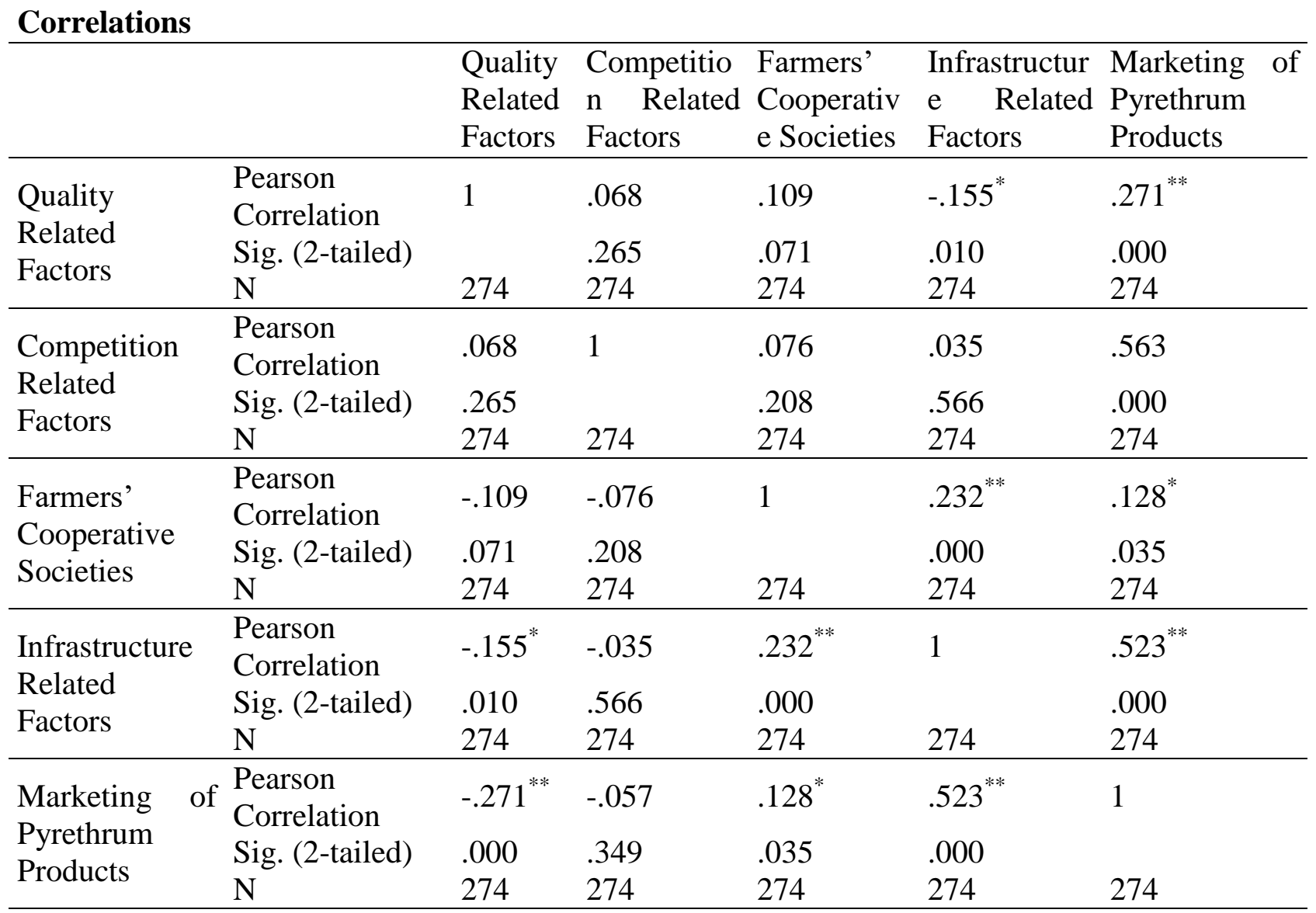

*. Correlation is significant at the 0.05 level (2-tailed).

$H_{01:}$ There is no significant influence of quality related factors on marketing of pyrethrum products by smallholder farmers in Kisii County

Data was analyzed using Pearson's correlation. The results in Table 2 indicate that there is a positive significant relationship between quality related factors and marketing of pyrethrum products by smallholder farmers $(r=0.271, p<0.05)$. Therefore according to the results, the hypothesis that: There is no significant influence of quality related factors of marketing of pyrethrum products by smallholder farmers in Kisii County was rejected. Therefore it was concluded that quality related factors have a positive influence on marketing of pyrethrum products by smallholder farmers in Kisii County.

These findings are consistent with the reviewed literature where Aaker and Jacobson (1994) reported that perceived product quality is related to increased sales and profits and consumers make their purchase decisions in relation to perceived quality. Thus the finding of the study empirically confirms the perspective that quality related factors influence the marketing of pyrethrum products by smallholder farmers. 
$H_{02:}$ There is no significant influence of competition related factors on marketing of pyrethrum products by smallholder farmers in Kisii County

Data was analyzed using Pearson's correlation. The results in Table 2 indicate that there is a positive significant relationship between competition related factors and marketing of pyrethrum products by smallholder farmers $(\mathrm{r}=0.563, p<0.05)$. Therefore according to the results, the hypothesis that: There is no significant influence of competition related factors on marketing of pyrethrum products by smallholder farmers in Kisii County was rejected. Therefore it was concluded that competition related factors have a positive influence on marketing of pyrethrum products by smallholder farmers in Kisii County.

These findings are consistent with the reviewed literature where (Contant, 1985) observe that in the fight for market share, competition is not manifested only in the other players. Rather, competition in an industry is rooted in its underlying economies, and competitive forces that go well beyond the established combatants in a particular industry. Thus the finding of the study empirically confirms the perspective that competition related factors influence the marketing of pyrethrum products by smallholder farmers.

\section{$H_{03:}$ There is no significant influence of farmers' cooperative societies on marketing of pyrethrum products by smallholder farmers in Kisii County}

The study sought to examine the influence of farmers' cooperative societies on marketing of pyrethrum products of smallholder farmers. It was hypothesized (Hypothesis $\mathrm{H}_{03}$ ) that farmers' cooperative societies have no significant influence on marketing of pyrethrum products by smallholder farmers. Data was analyzed using Pearson's correlation. The results in Table 2 indicate that there is a positive significant relationship between farmers' cooperative societies and marketing of pyrethrum products by smallholder farmers $(\mathrm{r}=0.128, p<0.05)$. Therefore according to the results, the hypothesis that: There is no significant influence of farmers' cooperative societies on marketing of pyrethrum products by smallholder farmers in Kisii County was rejected. Therefore it was concluded that farmers' cooperative societies have a positive influence on marketing of pyrethrum products by smallholder farmers in Kisii County.

The findings support the argument by Quint (2014) who observed that while many cooperatives may have struggled and disappeared, others have recast themselves in order to cope better with the changes in global markets. Cooperatives and rural associations are now resurgent business forms in Africa. Thus the finding of the study empirically confirms the perspective that farmers' cooperative societies influence the marketing of pyrethrum products by smallholder farmers.

\section{$H_{04:}$ There is no significant influence of infrastructure on marketing of pyrethrum products by smallholder farmers in Kisii County}

Data was analyzed using Pearson's correlation. The results in Table 2 indicate that there is a positive significant relationship between infrastructure related factors and marketing of pyrethrum products by smallholder farmers $(\mathrm{r}=0.523, p<0.05)$. Therefore according to the results, the hypothesis that: There is no significant influence of infrastructure related factors on marketing of pyrethrum products by smallholder farmers in Kisii County was rejected. Therefore it was concluded that infrastructure related factors have a positive influence on marketing of pyrethrum products by smallholder farmers in Kisii County.

The findings of the study agrees with literature that Kenyan traders in agricultural produce face high transportation and other transaction costs due to poor roads and other market inefficiencies. These costs have been shown to influence the agricultural sector as they influence the difference between farm gate 
prices and retail prices in the final consumer market - the marketing margin. Thus the finding of the study empirically confirms the perspective that infrastructure related factors influence the marketing of pyrethrum products by smallholder farmers.

$H_{05:}$ Quality related factors, competition related factors, farmers' Cooperative societies, and infrastructure related factors jointly do not have a significant influence on marketing of pyrethrum products by smallholder farmers in Kisii County

The study ascertained the influence of quality related factors, competition related factors, farmers' cooperative societies, and infrastructure related factors on marketing of pyrethrum products of small holder farmers in Kisii County. The results in relation to the foregoing are illustrated in Tables 3 . The model in Table 3 shows the influence of selected factors on marketing of pyrethrum products among small holder farmers. The Model shows that R Square is 0.321, which shows that $32.1 \%$ of the variation in marketing of pyrethrum products among small holder farmers is explained by quality related factors, competition related factors, farmers' cooperative societies, and infrastructure related factors.

Table 3: Multiple Regression Results for the Effect of Selected Factors on Marketing of Pyrethrum Products among Small Holder Farmers.

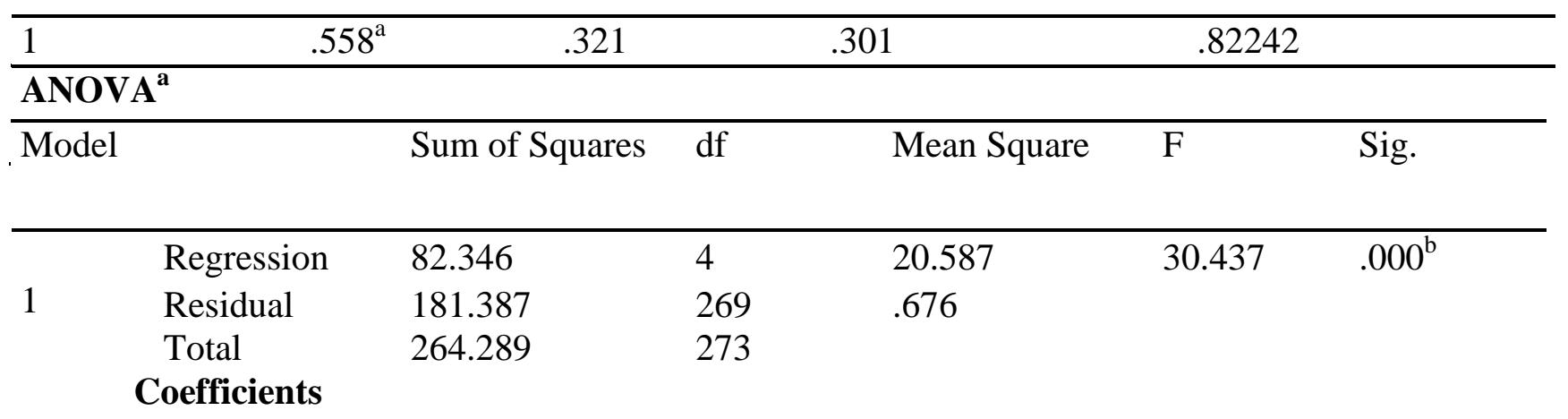

\begin{tabular}{lllll}
\hline Model & $\begin{array}{l}\text { Unstandardized } \\
\text { Coefficients }\end{array}$ & $\begin{array}{l}\text { Standardized } \\
\text { Coefficients }\end{array}$ & $\mathrm{t}$ & Sig.
\end{tabular}

\begin{tabular}{|c|c|c|c|c|c|c|c|}
\hline & & & Beta & Std. Error & Beta & & \\
\hline \multirow{5}{*}{1} & (Constant) & & 1.371 & .371 & & 3.694 & .000 \\
\hline & Quality Relate & d Factors & .241 & .147 & .421 & 1.640 & .008 \\
\hline & $\begin{array}{l}\text { Competition } \\
\text { Factors }\end{array}$ & Related & .219 & .144 & .286 & 1.517 & .036 \\
\hline & $\begin{array}{l}\text { Farmers' } \\
\text { Societies }\end{array}$ & Cooperative & .173 & .117 & .317 & 1.481 & .045 \\
\hline & $\begin{array}{l}\text { Infrastructure } \\
\text { Factors }\end{array}$ & Related & .907 & .096 & .495 & 9.423 & .000 \\
\hline
\end{tabular}

a. Predictors: (Constant), Quality Related Factors, Competition Related Factors, Farmers' Cooperative Societies, Infrastructure Related Factors

b. Dependent Variable: Marketing of pyrethrum products of small holder farmers 
The ANOVA demonstrates test for the combined effect of quality related factors, competition related factors, farmers' cooperative societies, and infrastructure related factors on marketing of pyrethrum products among small holder farmers. The ANOVA results show that the model was significant $(\mathrm{F}=$ $30.587, p<0.05)$. This indicates that quality related factors, competition related factors, farmers' cooperative societies, and infrastructure related factors jointly have a positive and significant effect on marketing of pyrethrum products of small holder farmers. The standardized coefficients show that the effect of quality related factors on marketing of pyrethrum products among small holder farmers is positive and significant $(\beta=0.421, \mathrm{t}=1.640, p<0.05)$, the effect of competition related factors on marketing of pyrethrum products among small holder farmers is positive and significant $(\beta=0.286, \mathrm{t}=$ $1.517, p<0.05)$, the effect of farmers' cooperative societies is positive and significant $(\beta=0.317, \mathrm{t}=$ $1.481, p<0.05$ ). Finally the effect of infrastructure related factors on marketing of pyrethrum products among small holder farmers is positive and significant $(\beta=0.495, \mathrm{t}=9.423, p<0.05)$.

The full regression model in Table 3 can also be interpreted to show how dimensions of selected factors affect marketing of pyrethrum products by smallholder farmers. The unstandardized coefficients show that for every unit increase in quality related factors, a 0.241 unit increase in marketing of pyrethrum products by smallholder farmers is predicted holding other variables constant. For every unit increase in competition related factors, a 0.219 unit increase in marketing of pyrethrum products by smallholder farmers is predicted holding other variables constant. For every unit increase in farmers' cooperatives, a 0.173 unit increase in marketing of pyrethrum products by smallholder farmers is predicted holding other variables constant. Finally for every unit increase in infrastructure related factors, a 0.907 unit increase in marketing of pyrethrum products by smallholder farmers is predicted holding other variables constant. From these findings we can infer that infrastructure related factors were influencing the marketing of pyrethrum of smallholder farmers most, followed by quality related factors, and then competition related factors and finally farmers' cooperative societies.

\section{CONCLUSION}

The results of the study revealed that there is significant influence of the selected factors on the marketing of pyrethrum products by smallholder farmers in Kisii County. The findings of the study lead to the following conclusions:

The first objective was to establish the influence of quality on marketing of pyrethrum products of smallholder farmers in Kisii County. The findings indicate that the pyrethrum farmers in Kisii County are paid based on the quality of their dry flowers exhibited by quality factors such as dryness, cleanliness and especially on the pyrethrin content. The findings revealed that for every unit increase in quality related factors, a 0.241 unit increase in marketing of pyrethrum products by smallholder farmers is predicted holding other variables constant.

The second objective was to establish the influence of competition related factors on the marketing of pyrethrum products of smallholder farmers in Kisii County. The findings reveal that three thirds of the farmers in the area of study do not prefer pyrethrum as their number one cash crop since it is facing competition for acreage from other crops such as beans and bananas. However, a third of the farmers rated pyrethrum as their number one cash crop. The findings also revealed that for every unit increase in competition related factors, a 0.219 unit increase in marketing of pyrethrum products by smallholder farmers is predicted holding other variables constant.

The third objective was to determine the influence of farmers' cooperative societies on the marketing of pyrethrum products of smallholder farmers in Kisii County. The findings of the study indicate that Farmers' cooperative societies play a key role in consolidation of pyrethrum products for ease of 
transportation to the market. It was also revealed that payments for delivered pyrethrum flowers are made through the FCSs though the payments from PBK are not prompt. The findings revealed that for a unit increase in farmers' cooperatives societies, a corresponding 0.173 unit increase in marketing of pyrethrum products by smallholder farmers is predicted holding other variables constant.

The fourth objective was to determine the influence of infrastructure related factors on marketing of pyrethrum products of small holder farmers in Kisii County. The findings indicated that most roads in Kisii County are neither gravelled nor tarmacked. The farmers experience difficulties in transporting their dry flowers from the collection centers to the market. The findings also revealed that for every unit increase in infrastructure related factors a 0.907 unit increase in marketing of pyrethrum products by smallholder farmers is predicted holding other variables constant.

The fifth objective was to determine the joint influence of the selected factors of quality related factors, competition related factors, famers' cooperative societies and infrastructure related factors on marketing of pyrethrum products from smallholder farmers in Kisii County. From the findings we can infer that infrastructure related factors were influencing the marketing of pyrethrum of smallholder farmers the most, followed by quality related factors, and then competition related factors and finally farmers' cooperative societies influencing the least.

\section{REFERENCE}

I. Aaker, D. \& Jacobson, R., (1994), "The financial information content of perceived quality", Journal of Marketing Research, 31, (2) 191-201.

II. Abbott, C (1988) Agricultural Processing for Development Avebury /Gower, Hantz.U.K. Adjustment in Kenya', in Gibbons, P. (ed.), Social Change and Economic Reform in Africa.

III.Anderson, J. R., (1992). Difficulties in African agricultural systems enhancement? Ten hypotheses, Agricultural Systems, 38, 387-409.

IV. Anderson, K. and Valenzuela, E. (2008). Estimates of Distortions to Agricultural Incentives, 1955 to 2007, spreadsheet at www.worldbank.org/agdistortions, World Bank, Washington DC.

V. Babbie, E. (2002). Survey research methods ( ${ }^{\text {nd }}$ ed.). Belmont: Wodsworth.

VI. Bagnoli, Mark, \& Ted Bergstrom. (2005) Log-Concave Probability and Its Applications. "Economic Theory 26(2):445-469.

VII. Baker, D. (1992). The Inability of Farming Systems Research to Deal with Agricultural Policy" in ODI Agricultural Administration (Research \& Extension) Network Paper (35) 1992.

VIII. Barham, J. \& Chitemi, C. (2009). Collective action initiatives to improve Marketing performance; Lessons from farmer group in Tanzania Food policy 34(1).

IX. Barrett, C. B. 2008. Smallholder market participation: concepts and evidence from eastern and southern Africa. Food Policy, 33(4): 299-317.

X. Bernard, T., \& Spielman, D. J. (2009). Reaching the Rural Poor Through Rural Producer Organizations? A study of agricultural marketing cooperatives in Ethiopia. Food Policy, 34(1), 60-69. http://dx.doi. org/10.1016/j.foodpol.2008.08.001.

XI. Bonnen, J. (1986) "A Century of Science in Agriculture: Lessons for Science Policy" Amer. J. Ag. Ec. 68: 1065-80. Regional Rural Development

XII. Buzzell, D., Gale, T. \& Sultan, R. G. M., (1975). "Market share- a key to profitability", Harvard Business Review, 53, (1) 97-106.

XIII. Capon, N., Farley, U. \& Hoenig, S., (1990). "Determinants of financial performance: a metaanalysis", Management Science, 36, (10) 1143-1159.

XIV. Chapoto, A., Haggblade, S., Hichaambwa, M., Kabwe, S., Longabaugh, S., Sitko, N., and Tschirley, D. (2013). Institutional Models for Accelerating Agricultural Commercialization: 
Evidence from Maize, Cotton and Horticulture. No. 154940. Michigan State University, Department of Agricultural, Food, and Resource Economics.

XV. Chaturvedi, N (1959) .: The Theory of Marketing in Underdeveloped Countries_Kitab Mahal Publishers. Allahabad. 1959. 3

XVI. Contant B .1979. 'pyrethrum' in Evolution Crop Plants ed. By simonds 33

XVII. Contant, R. (1985). 'pyrethrum' in Evolution Crop Plants ed. By simonds p.33

XVIII. Daniel Quint (2014). Imperfect competition \& substitutes .Univeristy of winsconsin

XIX. Dell'Osso, T. \& Filippo. R. (1990). When leaders become followers: The market for anti-ulcer drugs. Case series no. 12. London Business School. February.

XX. Deller, S., Hoyt, B. Hueth \& R. SundaramStukel.(2009). Research on the Economic Impact of Cooperatives. University of Wisconsin Center for Cooperatives. Available Online: http:// reic. uwcc. wisc. edu /sites/all/ REIC_FINAL. pdf

XXI. Export Processing Zones Authority, EPZA (2005). An Overview for Investors: "Kenya's Pyrethrum Industry"

XXII. FAO (1993), Women's activities in Food and Agriculture Marketing in Developing Countries: FAO, Kenya, Agriculture Sector Brief, April 2004.

XXIII. FAO, Kenya: Food Security and Agriculture Development Horizon 2015, November 2003 (Draft).

XXIV. FAO. (2001) The state of food and agriculture - Economic impacts of trans-boundary plant pests and animal diseases. Rome.

XXV. FAO. (2003) World agriculture towards 2015/2030: An FAO Perspective. Earth scan, London.for International Development.

XXVI. FAO.(1997) Report on the 1990 World Census of Agriculture: International comparison and primary results by country (1886-1995), Statistical Development Series 9, FAO. Rome.

XXVII. Fischer E., Qaim M. (2012). "Smallholder Farmers and Collective Action; What Determines the Intensity of Participtation?" Paper prepared for the Seventh Annual Conference of the Verein für Socialpolitik - Research Committee Development Economics

XXVIII. Fischer, E., Qaim, M. (2012). Gender, Agricultural Commercialisation, and Collective Action in Kenya.The International Association of Agricultural Economists (IAAE) Triennial Conference, Foz do lguacu, 18-24 August 2012.

XXIX. Gadzikwa. L., Lyne. M.C., Hendriks S.L. (2007). "Horizontal Cordination and Freeriding in a Group of Certified Organic Crop Growers: An Empirical Study of the EzemvdoFarmers' Organization in Kwazulu Natal, South Africa". African Journal of Agricultural and Resource Economics, 2:129-144.

XXX. Galor Z. (1985) "Towards the Cooperative Development Traditional Rural Areas". IIDCLS. Tel Aviv 1985

XXXI. Ganewatta, G and Waschik, Robert and Jayasuriya, S and Edwards, G (2005) Moving up the processing ladder in primary product exports: Sri Lanka's "value-added" tea industry. Agricultural Economics, 33 (3). 341 - 350. ISSN 0169-5150

XXXII. Gasmi, F., Laffont, Q., \& Vuong, H. (1990). A structural approach to empirical analysis of collusive behavior. European Economic Review 34:(5) 13-23.

XXXIII. Gatarwa. K., Place.F. (2005). "Initiatives for Rural Development through Collective Action The case Study of Household Participation in Group Activities in Highlands of Central Kenya'. CAPRi Working Paper, Washington DC.

XXXIV. Gitu Kang'ethe W. \& Cameron Short, H. (1990). Problems and Opportunities for improving land use efficiency in the high and medium potential areas: focus on daily 
production. Technical paper 90-06. Republic of Kenya. Ministry of Planning and National Development, September 1990.

XXXV. Government of Kenya, (2013). Pyrethrum Act, 2013 (No. 22 of 2013).

XXXVI. Hudson, D., Herndon, C.W., (2002). "Factors influencing Probability and Frequency of Merger and Partnership Activity in Agriculture Cooperatives". Agribusiness Journal, 2:231246.

XXXVII. IEA, Kenya at the Crossroads (2001), Institution of Economic Affairs (IEA, Kenya) and Society.

XXXVIII. IFAD (2004). A Review of Agricultural Marketing in Kenya. Consultancy Report, International Fund for Agricultural Development (IFAD), Rome.

XXXIX. Ikiara, K Juma, A \& Amadi, J. (1993), ‘Agricultural Decline, Politics and Structural International.

XL. Inyamu, G. (2006). Evaluation of the efficiency of primary pyrethrum marketing channels: A case study of Nakuru District. Unpublished Masters Thesis, Egerton University. pp 80-88.

XLI. Jovetics, S. (1994). 'Natural Pyrethrins and Biotechnological Alternatives', Biotechnology Development Monitor, No. 21.

XLII. Kamau T.N. (2016). An Econonic Analysis of Factors Influencing Participation in Pyrethrum Group Marketing Channels among Farmers in Nyandarua County, Kenya. Masters Thesis, The University of Nairobi

XLIII. Kaminski, J., Headey, J., and Bernard, T. (2009). Institutional Reform in the Burkinabè Cotton Sector and its Impacts on Incomes and Food Security 1996 - 2006. IFPRI Discussion Paper 00920 Nov 2009 http://www.ifpri.org/sites/default/files/ publications/ifpridp00920.pdf

XLIV. Kariuki, G. \& Place, F. (2005). Initiatives for rural development through collective action: The case of household participation in group activities in the highlands of central Kenya. CAPRi working paper, Washington D.C.: International Food and Policy Research Institute.

XLV. Kariuki, K. (2006). Revamping the Pyrethrum Sub-sector in Kenya Through Value Addition. Discussion Paper No. 085/ 2006, Institute of Policy Analysis and Research (IPAR), Nairobi.

XLVI. Kenya Dairy Development Policy (2000).Toward development of a sustainable dairy industry.

XLVII. Kothari,C.R.(2009) Research Methodology: Methods and Techniques.New Delhi:New Age International Publisher

XLVIII. Kotler, P. \& Keller, K. (2006). Marketing Management, 12th ed. Pearson Prentice Hall.

XLIX. La Ferrara, E., 2002. Inequality and group participation: theory and evidence from rural Tanzania. Journal of Public Economics 85(2), 235-273.

L. Lapar, M.L., Holloway, G., Ehui, S. (2003). "Policy Options Promoting Market Participation Among Smallholder Livestock Producers: A Case Study of Phillipines." Food Policy Journal, $3: 187-211$.

LI. Leffler, T. \& Keith B. (1981). Persuasion or information? The economics of prescription drug advertising. Journal of Law and Economics 24 (April): 45-14.

LII. Lundy, M., Ostertag, C. \& Best, R. (2002). Value adding, agro-enterprise and poverty reduction: A territorial approach for rural business development. Rural agro-enterprise development project paper. Cali, Colombia: International Center for Tropical Agriculture

LIII. Markelova, H., Meinzen, R., Hellin, J. and Dohrn, S. (2009). Collective action for smallholder market access, Food Policy. 34 (2009), p.1-7 
LIV. McGuire, B., Schneeweis, T. \& Branch, B., (1990). "Perceptions of firm quality: a cause or result of firm performance", Journal of Management, 16, (1) 167-180.

LV. $\quad$ McLoughin, M. (1970)." In Sukumaland: Tanzania". In Bunting AH. (ed.) (1970) pgs 411-420.

LVI. Meizen-Dick R, DiGregorio M, McCarthy N. (2004). "Methods for Studying Collective Action in Rural Development". SP-PRCA Working Papers No.33. Washington, DC: IFPRI. pp 23.

LVII. Micheal porter (1997) How competition forces shape strategy .Havard business school. Review report Nordiska African Institute Upsalla.

LVIII. Ministry of Finance Planning and Economic Development, MFPED (2004). Background to the Budget for Financial Year 2004/05: "Promoting Economic Growth and Reducing Poverty through Public Expenditure" (Abstract), MFPED, Kampala. 77

LIX. Monda, J.M. (2014). "Pyrethrum Farmers Look to Liberalization to Reverse Fortunes, A Paper Presented During the Regional Trade and Policy Workshop, Nairobi. pp 4.

LX. Mugenda D., Mugenda A. (1999). Research methods: Quantitative and Qualitative Approaches, Nairobi, Kenya Act Press. pp 143-161.

LXI. Mugenda, A. (2008). Social Science Research. Acts Press. Nairobi. Kenya RAND Journal of Economics 38(4):1159-1179

LXII. Muricho, G. (2002). "Impact of Transaction Costs on the Marketing of Dry Pigeon Pea in Makueni District". Unpublished MSc Thesis University of Nairobi. pp 63-69.

LXIII. Narrod, C., Roy, D., Okello, J., Avendaño, B., Rich, K., Thorat, A. 2009. Public-private partnerships and collective action in high value fruit and vegetable supply chains. Food Policy $34(1), 8-15$.

LXIV. Ndubi, J.M., Ouma, J.O. and Murithi, F.M. (2000). "Banana Marketing in Eastern province of Kenya". A Survey Report. Proceedings of the 7th KARI Scientific Conference. KARI Headquarters Nairobi-Kenya. pp 237-242.

LXV. Ngigi, M., Delgado, C., Staal, C.J. and Mbogo, S. (2000). "The Role of Market Outlet in Determining Terms for Milk Sales by Smallholders in Kenya". Unpublished paper presented at the annual meetings of the American Agricultural Economics Association, Tampa, Florida, USA. pp 12.

LXVI. Ngugi, C.W., Ikahu, J.M.K. Gichuru, S.P. (1999). Determination of Regional and Aggregate Price Elasticity in Pyrethrum Industry in Kenya. Pyrethrum Post, 17(2):52-55.

LXVII. Niven, U., Reardon, T., Chege, J., Odera, MM., Weatherspoon, D., Mwaura, F. O. (2005). "The Rapid Rise of Supermarkets in Kenya: Impact on Fresh Fruits and Vegetables Supply Systems". World Development 37(11):1802-1811.

LXVIII. Njuki, J., Kaaria, S., Sanginga, P., Kaganzi, E., Magombo, T. (2006). Empowering Communities through Market Led Development. Community Agro-Enterprise Experiences from Uganda and Malawi. New York, Oxford University Press. p 26.

LXIX. Nkonya, E., Kato, E. (2001).Agricultural Input Marketing in Uganda International Food Policy Research Institute (IFPRI). The IFPRI Policy Workshop, Kampala, 25-26 June 2001. 78

LXX. Nunnally, J. C. (1978). Psychometric theory ( $2^{\text {nd }}$ ed.). New York: McGraw-Hill.

LXXI. Nyangito, H., Ndirangu L. (1998). "Farmers response to reforms in the marketing of maize in Kenya". A case study of Trans Nzoia District. IPAR discussion papers series.

LXXII. Obare, A.O., Bekele, A.S., Muricho, (2005). "Strategic Assessment and Development of Pathways for Agriculture in the Semi-arid Areas of Kenya". ICRISAT, Nairobi, Kenya. 
LXXIII. Odulaja, A., Kiros, F.G. (1996). Modelling Agricultural Production of Small-Scale Farmers in Sub-Saharan Africa: A Case Study in Western Kenya. Agricultural Economics, 14:85-91.

LXXIV. Okoboi, G. (2001). The Marketing Potential of Potatoes in Uganda and Market Opportunities for Rwanda. Journal of International Development, 9:117-131.

LXXV. Olwande, J., Mathenge, M. (2012).Market Participation among Poor Rural Households in Kenya. The International Association of Agricultural Economists (IAAE) Triennial Conference, Foz do lguacu, 18-24th August 2012.

LXXVI. Omiti, J.M., Otieno, D.J., Nyanamba, T.O., McCullough, E. (2009). Factors Influencing the Intensity of Market Participation by Smallholder Farmers: A Case Study of Rural and PeriUrban Areas of Kenya. African Journal of Agricultural and Rural Economics, 3:57-82.

LXXVII. Owuor, G. (2009). Can Group Based Credit Uphold Smallholder Farmers Productivity and Reduce Poverty in Africa? Empirical Evidence from Kenya. Seminar paper presented at 111 EAAE-IAAE seminar 26th to 27th June 2009, University of Kent, Canterbury, United Kingdom.

LXXVIII. Poulton, C., Leavy, J. (2007). Commercialisations in Agriculture. A Working Paper, Future Agricultures, School of Oriental and African Studies (SOAS), University of London, London.

LXXIX. Pravakar, S., Castellanos, I.V., Rahut, D.B. (2010). Commercialization of Agriculture in the Himalayas. IDE Discussion Paper No. 265. 79

LXXX. Pyrethrum Board of Kenya, PBK (2010). Annual Report

LXXXI. Republic of Kenya (2006). The Making of Kenya: Our Vision for Prosperity (Vision 2030). National Economic and Social Council (NESC), Office of the President, Nairobi

LXXXII. Republic of Kenya (2006a). Trade and Industrial Policy (Draft Zero), Ministry of Trade and Industry, Nairobi.

LXXXIII. Republic of Kenya (2006b). Economic Survey, Central Bureau of Statistics (CBS), Ministry of Planning and National Development, Nairobi.

LXXXIV. Republic of Kenya, Ministry of Planning and National development 1998. Economic survey.p99

LXXXV. Roberts, Mark J.,\& Larry Samuelson, T. (1988) An empirical analysis of dynamic, nonprice competition in an oligopolistic industry. Rand Journal of Economics 19 (2): 200-220

LXXXVI. Ronge, E., Njuguna, K. (2010). Kenya's Trade Flows of Agricultural and Manufactured Commodities and Impacts of WTO agreements. Agricultural Economics, 7:374-380.

LXXXVII. Schuh. E, (1982).Food Aid as a Component of General Economic and Development Policy; Selected Readings CTA, Technical Center for Agricultural and Rural Cooperation $\mathrm{CAB}$

LXXXVIII. Scouler, Bonnie Jean. (1993) A segmentation analysis of the ulcer drug market. Thesis, of Management, Massachusetts Institute of Technology

LXXXIX. Strasberg, P.J., Jayne, T.S., Yamano, T., Nyoro, J., Karanja, D., Strauss, J., 1999. Effects of Agriculture Commercialization on Food Crop Input Use and Productivity in Kenya, MSU International Development Working Papers No. 71.

XC. Strauss, A. \& Corbin, J. (1998) Basics of Qualitative Research: Techniques and procedures for developing grounded theory, Thousand Oaks, California: SAGE Publications.

XCI. Strauss, A., \& Corbin, J. (1998). Basics of qualitative research $\left(2^{\text {nd }}\right.$ edition). London, Thousand Oaks, New Delhi: SAGE Publications Ltd

XCII. Sutton, John, Y. (1991) Sunk costs and market structure. Cambridge: MIT Press 
XCIII. Thomas W. Gray \& Charles Kreazier, H. (2014). Problems facing farmers' cooperatives. Rural business Co-operatives, research report 192

XCIV. Thurston, A (1984) The Intensification of Small-holder Agriculture in Kenya: The Genesis and Implementation of the Swynnerton Plan - Oxford Development Records Collected Papers 96

XCV. Van Heck, B (2003). "Participatory Development: Guidelines on Beneficiary Participation in Agricultural and Rural Development". Rural Institutions and Participation Service, Rural Development Division, FAO, Rome, Italy. pp 47-58.

XCVI. WBCSD (2004). Pyrethrum Sourcing from Kenya. Case Study Report. World Business Council for Sustainable Development (WBCSD), Geneva.

XCVII. World Bank (2008). World Development Report, Agriculture for Development. The World Bank, Washington DC. pp 43-50.

XCVIII. World Bank (2011). World Development Report, Agriculture for Development. The World Bank, Washington DC. pp 71.

XCIX. World Bank, (1990).Agriculture Growth Prospect Strategy Options, Vol. 2: Annexes. 